\title{
Jerónimo Velázquez. Un hombre de teatro en el período de gestación de la comedia barroca
}

\author{
Carmen Sanz Ayán * \\ Bernardo J. García Garcia **
}

Cuando hablamos del teatro clásico español, nuestros resortes mentales nos conducen de modo casi automático a los nombres de poetas como Lope de Vega o Calderón, cuyo quehacer literario representó un legado universal para las letras del Siglo de Oro y cuyas obras supusieron un testimonio singular e inmejorable de los siglos XVI y XVII.

Quizá recordemos también ese universo social que significaron los corrales de comedias; alli se daban cita buena parte de los distintos grupos existentes en la sociedad de Antiguo Régimen. Las mujeres del pueblo en la "Cazuela», los hombres de a pie en el patio, los menestrales y tenderos en las gradas, la nobleza en las ventanas y aposentos y el clero masculino en la tertulia.

Todos compartian el espacio del corral, aunque entraban por puertas distintas, como diferentes eran también sus lugares de estancia. Todos presenciaban el mismo espectáculo, pero éste era a su vez tan diverso que satisfacia en un momento o en otro los gustos más exigentes del público desigual que lo contemplaba.

Los bailes y entremeses revolucionaban a la mosquetería y a la cazuela, los monólogos del «galán» o del «barba» asombraban a las damas y eran motivo de disquisiciones filosóficas, o acaso teológicas, entre los frailes del desván; el buen hacer y decir de las actrices era motivo de comentario de los nobles y de alguna que otra acción más atrevida después y aún antes de la representación.

* Profesora Titular Universidad Complutense. Madrid.

** Becario Universidad Complutense. Madrid. 
Todo esto hacía que el teatro fuera considerado por estos años el espectáculo por excelencia y como tal forma parte del cuadro que nuestra imaginación forja cuando nos situamos en los años finales del quinientos y siguientes.

Sin embargo, comparativamente, sabemos muy poco de los hombres que montaban, dirigian y materializaban el espectáculo. Si llegaramos a conocerlos, podriamos obtener claves muy interesantes para comprender la propia eclosión, importancia y significación del teatro barroco.

El teatro fue por estos años no sólo una manifestación artística y literaria de primera magnitud o un medio de influencia y mediatización de las conciencias por parte del poder establecido - lo cual seria muy discutible-; fue además un negocio lucrativo montado y dirigido por unos hombres constituidos en verdaderos «empresarios» del espectáculo teatral.

Sabemos que los literatos podian vivir cómodamente de escribir obras para los escenarios si éstas tenian éxito. No era rentable hacer novelas u otro tipo de piezas literarias. El teatro era el único género que proporcionaba al mismo tiempo fama, prestigio y dinero. De ello dieron testimonio muchos hombres de letras y entre ellos el propio Cervantes, cuyo afán de triunfo en las tablas perduró durante casi toda su vida.

Los empresarios que compraban las obras de los poetas y les daban fama eran en el lenguaje de la época «los autores de comedias". De su actividad y de sus vidas conocemos algunas noticias, casi siempre escasas y que adornan como un detalle más las biografias de los escritores que ellos contribuyeron a inmortalizar.

Diez Borque señaló hace ya bastantes años que para acercarse al fenómeno del teatro barroco en toda su complejidad era necesario conocer de modo más profundo la vida de los autores de comedias '. En este sentido el presente estudio sobre Jerónimo Velázquez puede ser interesante no sólo porque nos permitirá reconstruir, en parte, el ambiente en el que se gestó y desarrolló el teatro durante el último cuarto del siglo XVı en la corte, -donde Jerónimo Velázquez desarrolló la mayor parte de su actividad-, sino porque además puede servirnos como paradigma ${ }^{2}$ del quehacer diario de los hombres que pusieron en marcha el fenómeno teatral

Diez Borque, J. M. Sociedad y teatro en la España de Lope de Vega. Barcelona 1978 , pág. 44.

Este artículo constituye una pequeña muestra de un trabajo más exhaustivo sobre los autores de comedias que operaron en la corte entre 1575 y 1625 y que estamos realizando en la actualidad dentro de un proyecto de investigación financiado por la Comunidad de Madrid. 
Jerónimo Velázquez. Un hombre de teatro en el período de ...

desde las mismas tablas, como actores, empresarios y directores del espectáculo por excelencia del siglo XV!I.

\section{JERÓNIMO VELÁZQUEZ Y EL TEATRO}

\section{Velázquez. Autor de comedias}

Tan sólo una primera aproximación al volumen de la actividad teatral de Velázquez puede indicarnos el puesto que le toca ocupar en el panorama teatral del último cuarto del siglo xvi. Velázquez fue el autor de comedias de más éxito en Madrid, si nos atenemos a su capacidad de recaudación, durante la década de los ochenta (1579-1586) ${ }^{3}$. En este periodo del naciente teatro barroco, las compañias de más éxito fueron las de Jerónimo Velázquez, Alberto Ganassa y Alonso de Cisneros. Pero con diferencia, Velázquez fue el autor que más rendimiento proporcionó a las cofradias de la Pasión y de la Soledad en Madrid durante el período aludido.

Ejerció una gran actividad en los escenarios peninsulares entre 1574 y 1598 de modo prácticamente ininterrumpido y se encargó de las representaciones de los autos sacramentales en las fiestas del Corpus de Madrid en nueve ocasiones que sepamos. A continuación, reconstruiremos lo más detalladamente posible su quehacer teatral en los escenarios peninsulares.

Agustín de Rojas cita a Velázquez en su Viaje entretenido, diciendo que fue «de los que adelantó la comedia con sus composiciones poéticas haciéndolas más virtuosas y costosas de trajes y galas».

Si intentamos fijar el inicio de su actividad teatral, ésta se sitúa aparentemente alrededor de 1564 cuando le encontramos representando ante la esposa de Felipe II, Isabel de Valois, en el Alcázar de Madrid haciendo una comedia durante las fiestas de Año nuevo ${ }^{3 \text { bis. }}$. En 1570 se compro-

\footnotetext{
${ }^{3}$ Las fuentes sobre la actividad de Jerónimo Velázquez en la década de los ochenta en Madrid se han extraido de un libro de contabilidad perteneciente a la cofradia de la Pasión que se encuentra en el Archivo Regional de la Comunidad de Madrid, Fondo Diputación Caja 5084, carpetilla 1, y que han sido tratados corvenientemente para obtener estos datos. En la actualidad J. E. Varey y su equipo trabajan sobre la totalidad de esta documentación que verá la luz muy pronto en la colección de Fuentes para la Historia del Teatro en España.

3 bis Archivo General de Simancas (AGS) Casa y Sitios Reales, leg. 398, fols.394 y 408. Estos documentos son cartas de pago de Jerónimo Velázquez que cobró por la representación 100 reales. Como curiosidad en estos papeles Velázquez no firma "porque no sabe».
} 
metió con el ayuntamiento de Segovia para representar dos autos sacramentales durante las fiestas del Corpus de ese año ${ }^{4}$. Para entonces da la impresión de que su actividad como autor de comedias ya se habia consolidado ${ }^{4 \text { bis. }}$

Cuatro años después, en marzo de 1574, llegó a un compromiso con las autoridades municipales para realizar tres autos sacramentales en Madrid ${ }^{5}$. Tras la firma de este acuerdo, se procuró los servicios de varios actores, entre ellos un tal Juan de Sigura que formó parte de su compañía al menos desde mayo de 1574 hasta el carnaval del año siguiente, y del que más tarde hablaremos ${ }^{6}$.

También conocemos una carta de obligación suya de junio de ese mismo año para pagar 27.000 maravedies a un carpintero que había empleado cierta cantidad de madera en las representaciones que Velázquez estaba realizando. Este material no era para los carros del Corpus, pues los autores de comedias no los encargaban directamente, sino que sólo los supervisaban. Asi pues, debía necesitarlo para el escenario del corral de la Pacheca o de la Puente donde trabajó por estos años ${ }^{7}$.

Tras la representación del Corpus de 1574, el ayuntamiento de Madrid le contrató para realizar los autos tanto de $1575^{8}$, como de $1576^{\circ}$ y

${ }^{4}$ Archivo Histórico de Protocolos de Madrid (AHPM) "Obligación de Jerónimo Velázquez, para hacer la fiesta del Corpus de Segovia» en Tomillo. A. y Pérez Pastor, C., Proceso de Lope de Vega por libelos contra unos cómicos. Madrid 1901, pág. 141.

4 bls Aunque hemos visto cómo para la segunda mitad de la década de los 60 Velázquez ya se dedica a la actividad teatral, todavia en los documentos notariales no alude a este trabajo como su verdadera profesion. Por ejemplo en un documento fechado en 1565 (AHPM. prot. 263. Gaspar Testa, 17-XII-1565) firma un poder para vender unas casas de la calle de Principe y en él figura la profesión de Albañil al lado del nombre de Jerónimo Velázquez.

5 Pérez Pastor, C., Nuevos datos acerca del Histrionismo Español. Burdeos 1914, vol. I, pág. 333. "Obligación de Jerónimo Velázquez, autor de comedias de hacer para la fiesta del Santísimo Sacramento de este año en Madrid tres autos, el uno de la pesca de San Pedro y otro de la Vendimia Celesíal y el otro del Rey Baltasar cuando en sus convites profanó los vasos del Templo, y poner todos los personajes y aderezos de vestidos (...) sin que el dicho Jerónimo Velázquez ponga cosa ninguna en lo que toca al aderezo y artificio de los dichos carros, porque solamente ha de disponer los personajes y vestidos y aderezos para ellos y para los dichos autos y gente para tirar y llevar los carros y por razón de lo susodicho esta villa le ha de dar y pagar 130 ducados...».

${ }^{5}$ Ibidem, pág. 334, Doc. completo en (AHPM), prot. 411, fol. 148 v. Hablaremos de él en el apartado dedicado a los actores con los que trabajó Velázquez.

ibidem, vol. I, pág. 335.

- Tomillo, A. y Perez Pastor, C., Proceso de Lope de Vega, op. cit, págs. 141-142, «en 10 de marzo de 1575 acordó el ayuntamiento de Madrid que los 63.000 mrvs que Velázquez ha de haber y cobrar, la mitad luego y la otra mitad para después de acabar la fiesta y pascua del Santisimo Sacramento dando fianzas por mitad».

9 Ibidem pág. 142: "Obligación de Jerónimo Velázquez, autor de comedias de representar tres autos en la próxima fiesta del Corpus». Madrid 14 de marzo de 1576. 
Jerónimo Velázquez. Un hombre de teatro en el periodo de ...

$1577^{10}$. Así pues, entre 1574 y 1577 Jerónimo Velázquez fue el autor más importante de comedias en la corte al monopolizar durante esos años las representaciones de los autos del Corpus. No hemos encontrado noticias suyas para 1578, pero a partir de aqui y hasta 1586 podemos reconstruir al detalle su actividad en la corte ${ }^{11}$.

Durante septiembre y octubre de 1579 Velázquez representó en Madrid en 15 ocasiones, siempre en el corral de la Puente (Ver Apéndice V: Calendario de las representaciones de Velázquez en la corte: 1579-1586). En estos momentos el corral de la Pacheca estaba ocupado por Ganassa, que se había instalado en Madrid en julio de ese año, protagonizando el momento más dulce de su carrera al representar en junio de ese año en Toledo ante Felipe II, hecho que le catapultó definitivamente a la fama ${ }^{12}$. Por su parte, la recaudación anual de Velázquez en Madrid para las cofradías, si la comparamos con la de Ganassa, fue modesta: unos 1.857 reales. Antes de instalarse en Madrid Velázquez habia estado representando en Valladolid ${ }^{13}$.

Los años 1580 y 1581 supusieron un paréntesis en la actividad teatral de Velázquez en Madrid, lo que no quiere decir que estuviera ausente de

10 Según documento inédito que se encuentra en AHPM, prot. 856 , fol. 235 r y $236 \mathrm{v}, \mathrm{y}$ que es un contrato entre jerónimo Velázquez y un menor llamado Garcia de Jaraba, se dice que Jerónimo Velázquez tiene a su cargo los autos del Corpus de ese año. Garcia de jaraba se concierta a cayudar en el dicho oficio de autor de comedias e representar con vos en todos los autos y farsas que hiciéredes... en todas partes, cibdades, villas e lugares destos reinos e señorios de S.M., más os ha de ayudar en las fiestas del dia del Corpus (1577) que vos el dicho Jerónimo Velázquez tenéis en esta villa de Madrid".

${ }^{11}$ Los datos utilizados para esta reconstrucción salen del libro de contabilidad de la cofradía de la Pasión que se encuentran en el Archivo Regional de la Comunidad de Madrid. Actualmente este libro parece ser el único que no se ha perdido de la serie que fue consultada por Pellicer y que menciona repetidas veces en su Tratado histórico..., aunque su contenido ha sido difundido fragmentaria y sintéticamente por Pérez Pastor o Rennert, todavía no ha sido objeto de un análisis sistemático ni se ha puesto en relación con un estudio de las compañias y representantes mencionados en él, carencia que confiamos se podrá subsanar con su edición crítica a cargo de J. Varey y las futuras aportaciones de la investigación que venimos desarrollando.

12 Alberto Nasseli alias "Ganassa", realizó en Madrid durante 1579 un total de 69 representaciones repartidas entre los meses de julio y diciembre sin prácticamente interrupción, 68 de ellas se realizaron en el corral de la Pacheca y tan sólo una en el de La Puente. Recaudó para las cofradias un total de $7.110,25$ reales. Sobre él existe algo más de bibliografia, aunque no puede decirse que haya trabajos exhaustivos que traten de su actividad en los escenarios. Algunas noticias en COTARELO Y MORI, «Noticias biográficas de Alberto Ganassa, cómico famoso del siglo xvI, Revista de Archivos, Bibliotecas y Museos, tomo XIX, 1908 , págs. 48 y ss.

13 Tenemos noticias de su estancia en esta capital por la compra de un "Agnus Dei» de plata que hizo en agosto de ese año, en Fernandez Martin, L., Comediantes, esclavos y moriscos en Valladolid. S xv y xvil. Valladolid, Universidad, 1988, pág. 27. 
la corte durante esos dos años completos. Lo cierto es que la década no habia empezado muy bien para los espectáculos teatrales, pues en octubre de 1580 murió la reina Ana de Austria, lo que supuso decretar un largo periodo de luto durante el cual los espectáculos teatrales en los corrales quedaban interrumpidos.

Aun asi, se puede constatar que en mayo de 1581 Velázquez contrajo una escritura de obligación en Madrid para ir a representar al colegio de San lidefonso de Alcalá de Henares un auto y unos entremeses ${ }^{14}$. Esto significa que muy probablemente se encargó de hacer estas representaciones en Madrid, quizá en funciones privadas, aprovechando después los aderezos y actores, como era tradicional, para repetirlos en pueblos de alrededor.

Hasta que se produjo la apertura oficial de los corrales de comedias, siguió realizando representaciones de tipo religioso. Por ejemplo, a comienzos de julio representó en Piedrahita (actual provincia de Ávila) dos autos con entremeses por encargo del arcipreste de aquella localidad $^{14}$ bis $y$ en agosto de ese año representó en la catedral de León dos autos a lo divino por el día de la Virgen de agosto y san Roque ${ }^{15}$.

Una vez levantado el período de cierre de los corrales, el grueso de su actividad, a finales de 1581, lo desarrolló en Valladolid, donde la cofradía de los Niños Expósitos le habia contratado desde el mes de noviembre, fecha en la que se inició la reapertura de los teatros. Allí consiguió un gran éxito de auditorio ${ }^{16}$, por lo que él y sus cómicos permanecieron sin interrupción hasta comienzos de enero ${ }^{17}$.

\footnotetext{
i4 Tomillo, A., y Pérez Pastor, C., op. cit., pág. 137, y AHPM, prot 768, fol. 52.

14 bus «Concierto de Jerónimo Velázquez, autor de comedias de Madrid con D. Francisco de Salazar y Rengifo, arcipreste de Piedrahita, por si y en nombre de la Cofradía del Rosario de la dicha villa, sobre ir con su compañia y estar en la citada villa el día postrero del presente mes y hacer en los dias primero y segundo de julio dos autos de la Sagrada Escritura, uno el día primero por la tarde y otro el dia segundo por la mañana y una comedia por la tarde, todo con sus entremeses y como es uso y costumbre y los dichos autos han de ser diferentes unos de otros y que no se hayan hecho en la dicha villa de Piedrahita. Esto por precio de 40.000 marvs. pagados al acabar de hacer dichas represeritaciones" Madrid nueve de junio de 1581. Tom!llo, A., y Pérez PAstor, C., op. cit., pág. 143

${ }^{15}$ Fernandez Martin, L., op. cit., pág. 28, «El licenciado Juan del Hoyo, vecino y abogado de esta Real Chancilleria en nombre del Ilustre Señor Deán y Cabildo de León, se concertó con Diego López de Cabrera, cirujano vecino de esta ciudad, en nombre de Jerónimo Velázquez, autor de representaciones, vecino de Madrid, que se obliga a hacer por el dia de Nuestra Señora de Agosto y Dia de San Roque, en la dicha Santa Iglesia de León dos autos a lo divino, a contento del Deán y Cabildo (...). Se le han de dar 108 ducados (...). Prot. 567, fol. 769 .

${ }_{16}$ Alonso Coftés, N., El Teatro en Valladolid. Madrid 1923, págs. 36-37.

17 Así lo demuestra un poder de Rodrigo de Saavedra, importante actor de la compañía
} 
A principios del año siguiente Velázquez volvió a Madrid con nuevos brios, realizando un total de cincuenta representaciones repartidas entre el corral de la Pacheca, quince, el de la Puente, una, y el de la Cruz, treinta y cuatro. Para entonces el teatro de las Obras Pías de la Calle de la Cruz era el que presentaba ya una mayor capacidad y actividad.

Velázquez trabajó en la corte de enero a junio con el paréntesis de marzo y no de abril a junio, como señalan los Anales del Teatro Español ${ }^{18}$. Repartió su actividad entre los tres corrales que funcionaban en la corte en esos momentos ${ }^{19}$. Durante estos meses compartió auditorio con Saldaña y Ganassa en enero y febrero, y con Cisneros de abril a junio. El volumen de recaudación que consiguió para las cofradias fue de 11.750 reales aproximadamente, cifra que lo distancia del resto de los autores. Además durante ese año se asoció con otras compañias, como la de Ganassa o Gálvez, para representar conjuntamente de manera esporádica. También durante ese año y asociado con Alonso de Cisneros, se encargó de hacer en Madrid los autos del Corpus ${ }^{20}$.

A partir de 1582 y hasta 1586, Jerónimo Velázquez recaló durante algunos meses en Madrid, manteniendo un volumen de recaudación bastante elevado. En 1583 entre los meses de octubre a diciembre, realizó treinta y tres representaciones, veintinueve de ellas en el corral de la Cruz y cuatro en el naciente corral del Príncipe. Durante estos meses coincidió con las compañias de Tomas de la Fuente, Alonso Rodríguez y Cisneros, acaparando la atención del público poco a poco, y llegando a ser casi el único autor de comedias en diciembre. Estas representaciones supusieron para las cofradias un total de 7.050 reales, lo que le colocaba en el segundo lugar entre los autores que más recaudación consiguieron ese año en Madrid.

También en 1583 sabemos que representó en Sevilla ${ }^{21}$, donde pidió junto con otro autor de comedias, Pedro de Saldaña, que la ciudad le

\footnotetext{
de Jerónimo Velázquez que autorizó a un tal Marcos de Paz para representarle en Valladolid. Fernández Martin, L., op. cit., pág. 28.

${ }^{18}$ Diaz de Escobar, N., Anales del teatro español correspondientes a los años 1581 a 1625. Madrid 1903, pág. 8.

19 Toda esta información sobre calendarios y lugares de representación de los autores de comedias activos en Madrid durante el último cuarto de siglo xvi se desprende del estudio que estamos llevando a cabo en la actualidad y que ha sido citado más arriba.

70 Tomilio, A., y Pérez Pastor, C., op. cit., pág. 143. "Obligación de Alonso de Cisneros y Jerónimo Velázquez, autores de comedidas para hacer un auto del Sacrificio de Abraham con dos entremeses, otro de la coronación de Nuestra Señora y otro auto sacramental, el que dijere el señor corregidor. Madrid 22 de marzo de 1582

2 Diaz de Escobar, N., Anales..., op. cit., pág. 11.
} 
concediera representar allí dos dias de trabajo por semana. Del mismo modo trabajó en Valladolid al menos durante el mes de septiembre ${ }^{22}$.

Durante 1584 aumentó su número de representaciones en la corte. En realidad no salió de Madrid al finalizar 1583. Realizó cuarenta y cinco funciones, treinta y tres de ellas en el teatro de las Obras Pias de la Calle de la Cruz, once en el corral del Principe y tan sólo una en el de la Puente, siencio ésta la última vez que representó en este viejo escenario. A partir de entonces lo hará siempre en los estables del Principe y de la Cruz.

Durante 1584 coincidió con Cisneros en Madrid, con el que compartió el teatro de la Cruz, mientras Ganassa y Saldaña se turnaban en el del Príncipe hasta los carnavales. Después de Cuaresma, Velázquez se quedó sólo en la corte. Da la impresión de que obtuvo un régimen de monopolio para representar en los dos corraies más importantes de la villa hasta que liegara el Corpus. Lo cierto fue que el concejo se aseguró la contratación de una compañía de renombre para la representación de los autos del Corpus de ese año a través de un medio bastante expeditivo. El 14 de febrero el ayuntamiento acordó que se notificara a Alonso de Cisneros, Jerónimo Velázquez, Alonso Rodríguez y Jerónimo de Gálvez y a sus representantes «que no hiciesen ausencia de esta Corte ellos o ninguno dellos hasta tanto que otra cosa por su merced se provea o mande" ${ }^{23}$. Tras este suceso, en marzo Velázquez se hizo cargo de nuevo de las representaciones de los autos en solitario ${ }^{24}$.

La recaudación de las cofradias por sus representaciones durante 1584 en los corrales que éstas administraban ascendió a 10.544 reales, lo que le colocaba de nuevo en el primer puesto entre los autores que representaron durante ese año en la corte. En este caso, como sucediera en 1582, permaneció en Madrid ininterrumpidamente de enero a junio y de nuevo, los tres autos del Corpus corrieron de su mano, cobrando por ello 113.900 maravedies ${ }^{25}$. Estos autos fueron los primeros que se repre-

\footnotetext{
"Un representante de su compañia, Jerónimo Rodriguez, firma ciertos poderes notariales en Valladolid durante el mes de septiembre. Fernandez MARTín, L., op. cit., pág. 28.

23 Pérez Pastor, C. Nuevos datos..., op. cit., vol. 11, págs. 13-14.

24 Tomillo, A., y Pérez Pastor, C., op. cit., págs. 143-144. «Obligación de Jerónimo Velázquez, autor de comedias, de hacer tres autos para las fiestas del Santisimo de este año en Madrid, por 113.900 mrvs: uno del retorno de Egipto, otro de Simón Mago y otro sacramental a elección del Ximénez Ortiz del Consejo de S.M. Obligase a dar la muestra 35 dias antes de la flesta (...) Pondrá vestidos de nuevo a todos los personajes". Madrid 2 de marzo de 1584.

${ }^{25}$ Uno de estos autos era de Lope de Vega muy amigo por estos años de Velázquez.
} 
Jerónimo Velázquez. Un hombre de teatro en el período de ...

sentaron en el ayuntamiento por la tarde después de comer pues los años anteriores se había hecho por la mañana desde las siete en adelante ${ }^{26}$.

Tras sus triunfantes representaciones en Madrid, marchó a Valencia donde representó en el corral de la Olivera entre el 22 de junio y el 15 de octubre. En Valencia la demanda teatral era también muy amplia, pues a comienzos de julio de ese año llegó Cisneros a aquella ciudad dispuesto a mostrar también su repertorio. Por ello el Hospital Real y General de la ciudad, beneficiario de las representaciones, habilitó un segundo corral provisional para que el recién llegado autor mostrara las habilidades de su compañía ${ }^{27}$.

En 1585 Velázquez redujo su actividad en Madrid. Sabemos que en julio se encontraba en Burgos representando. Tan sólo se registra su presencia en el teatro de la Cruz con un total de veintidós representaciones repartidas entre finales de noviembre y diciembre. El otro autor que se encontraba en estos momentos en la corte era Osorio. La corta actividad de Velázquez en la corte supuso para las cofradias un rendimiento de 5.452 reales. Continuó su actividad en Madrid a partir de enero del año siguiente ${ }^{28}$. Durante los meses de enero y febrero realizó treinta y cinco representaciones, treinta y tres en la Cruz y dos en el Principe, y su trabajo supuso para los hospitales el más alto rendimiento alcanzado en ese año por un autor teatral, concretamente 10.771 reales. De nuevo, las representaciones de los autos sacramentales del Corpus corrieron a su cargo cobrando esta vez 5.000 reales por ellas ${ }^{29}$.

En abril y mayo de ese año encontramos las pistas de Jerónimo Velázquez preparando todo lo necesario para la representación de los autos sacramentales de Madrid. Ya fuera inspeccionando los lugares donde se debian efectuar las representaciones, o acordando con los dueños de los carros los lugares en donde éstos debian estar el primer jueves del mes de junio ${ }^{30}$.

El compromiso de los autos del Corpus implicó de nuevo un cierto régimen de monopolio en las representaciones ordinarias que se hicieran

26 Tomillo, A., y Pérez Pastor, C., op. cit., pág. 144.

${ }^{27}$ Merimée, H., Spectacles et comédiens à Valencia (1580-1630). Toulouse 1913, pág. 30.

${ }^{28}$ Sabemos por fuentes indirectas que sus actuaciones continuaron hasta el día del Corpus, pero nuestras fuentes directas se interrumpen a finales de febrero de este año.

29 Pérez Pastor, C., Nuevos datos..., op. cit., vol. II, pág. 14.

${ }^{30}$ Doc. Inédito. AHPM, Cristóbal de Cuevas, prot. 862. «Juan Martinez y juan de Castro, ambos vecinos de Madrid se obligan a preparar y llevar ante las personas que les indicare Jerónimo Velázquez según es costumbre, seis medios carros que son tres por la mañana del dia del Corpus y que cuando acaben los volverán a su casa por precio de ciento dos ducados". Madrid 30 de mayo de 1586 
en los corrales de la villa hasta esa fecha, pues se estipulaba en el contrato que si entre la Pascua de Resurrección y el Corpus representaba alguien más en el término municipal de Madrid, se añadirian a los cinco mil reales, cien ducados más, to que suponia una compensación por retener a Velázquez en la corte hasta el día del Corpus ${ }^{31}$.

Precisamente en ese año Velázquez introdujo una novedad en las representaciones de corral que consistia en realizar funciones exclusivas para mujeres, Velázquez anunció dos representaciones en el corral del Príncipe, una por la mañana para mujeres solas y otra por la tarde. La convocatoria matinal tuvo un éxito resonante ya que acudieron $760 \mathrm{mu}$ jeres, pero el Consejo se opuso a esta innovación prohibiendo se ejecutase y mandó que el dinero recaudado quedara para obras pias ${ }^{32}$.

De toda la actividad descrita se deduce que a partir de 1582 Velázquez permaneció casi ininterrumpidamente en los escenarios madrileños desde septiembre hasta junio del año siguiente, es decir nueve meses. Si tenemos en cuenta que durante el verano la actividad en los corrales de Madrid se reducia, podemos deducir que su ámbito de actuación geográfica durante aquellos años no podía distar mucho de la corte, pues aparece puntualmente en otoño para iniciar un nuevo periodo de actividad teatral. Salvo alguna escapada ocasional a otros lugares, Sevilla, Burgos, León o Valladolid fueron, junto con Madrid, los lugares que más frecuentó.

Precisamente, en 1587 lo encontramos realizando los autos sacramentales de la ciudad hispalense ${ }^{33}$. A su vuelta a la corte estalló el escándalo por el que Jerónimo Velázquez es más conocido, el pleito con Lope de Vega. Durante aquel año Velázquez habia permanecido en Madrid haciendo la temporada de invierno, es decir de octubre a diciembre. Sus relaciones con Lope ya se habían roto y por ello no representaba sus obras. Esta circunstancia le acarreó problemas, pues le costaba encontrar comedias de otros poelas afamados.

Tras la publicación de las sátiras contra su familia, anónimas por supuesto, se le brindó la ocasión a Velázquez de presentar una querella con-

\footnotetext{
Pérez Pastor, C., Nuevos datos..., op. cit., vol. II, pág. 16.

${ }^{32}$ De este singular suceso se han hecho eco numerosos estudiosos. Tanto Diez de Escobar en sus Anales... pág. 15, como Rennert en su The Spanish Stage in the Time of Lope de Vega. Nueva York 1909, pág. 43.

33 Sentaurens, J., Seville et le Théâtre de la fin du Moyen Âge à la fin du XVIle siècle. Burdeos 1984, pág. 174
} 
Jerónimo Velázquez. Un hombre de teatro en el período de ...

tra Lope en la Sala de Alcaldes de Casa y Corte, pues contaba con pruebas que demostraban que el insigne poeta habia escrito los libelos ${ }^{34}$.

Tras el comienzo de las averiguaciones se amplió la información el 3 de enero de 1588 , estando ya preso el famoso poeta ${ }^{35}$. Durante la causa trataron de esclarecerse los móviles de Lope para arremeter tan sañudamente contra Velázquez. Dos pudieron ser las razones; una de ellas, la más conocida, las célebres «calabazas» de Elena Osorio hija de Velázquez al famoso poeta. La otra, menos romántica, pero seguramente de bastante peso, el hecho de que Velázquez al marcharse a Sevilla en 1587 no pidió las comedias a Lope para representarlas alli. Debemos recordar que por estos años Velázquez era el autor de comedias más importantes de Madrid y esto debió doler a Lope que tuvo que buscar otro autor que se las comprara ${ }^{36}$.

Quizá, alejado conscientemente de Madrid tras el revuelo surgido al presentar la querella por difamación y que tuvo como primer resultado la prisión de Lope el 29 de diciembre en el mismo teatro de la Cruz, Velázquez salió de la corte. En marzo de ese año, su yerno, Cristóbal Calderón, alquilaba con un poder de nuestro autor la casa de representación de Salamanca para actuar durante ia Pascual Florida ${ }^{37}$.

Después de haber trabajado durante abril y mayo en Salamanca, se encargó de los autos del Corpus en Valladolid. Alli le encontramos en junio de ese año pertrechándose de los vestidos necesarios para hacer estas representaciones ${ }^{38}$ y realizando algunas otras actuaciones de me-

$\hat{3}^{4}$ En uno de los poemas se infamaba a tres mujeres de la familia de Jerónimo veláz" quez, su sobrina, su esposa y su propia hija, acusando a las dos primeras de ser alcahuetas de la tercera. En otro de los poemas se atacaba al hijo de Velázquez acusándole de igno. rante y diciendo que por ser hijo de comediante se le debia negar la posibilidad de dedicarse a la abogacía. Tomillo, A. y Pérez Pastor, C., op. cit. pág. 139.

35 loidem, págs. 138-139.

36 El autor que le compró las comedias fue Gaspar de Porres. Su importancia fue grande durante la década de los noventa y primeros años del siglo xvil, pero a estas alturas su fama no podía compararse con la de Velázquez. Para más información sobre Gaspar de Porres ver ALLEN, J. J., "Gaspar de Porres, autor de Comedias", en Comedias y comediantes. Estudios sobre el teatro clásico español. Universidad de Valencia, 1991, págs. 337-348.

3i Fernández Maftín, L., op. cit., pág. 28. «Jerónimo Velázquez, autor de comedias, padre de Elena Osorio, da poder a Cristóbal Calderón, su yerno, para ir a Salamanca y "concertéis la casa de representación de dicha ciudad para representar en ella la Pascua de Flores de este año y los demás dias a tiempo que concertáredes y para recibir para mi compañía cualquier hombres y mujeres para representar en las figuras que se les encargasen, asentándoles el salario en que los concertantes se comprometieren, obligándome a que pagaré a la casa de representación, hospita! y cofradia de ella como a los dichos compañeros, los salarios en que os concertáredes y que pagaré la costa de los caminos y raciones". Valladolid 12 de marzo de 1588.

38 Ibidem, págs. 28-29 
nor importancia, por ejemplo en Santa Olalla de Paredes ${ }^{39}$, población situada en el camino entre Valladolid y Madrid.

En 1589 se encontraba de nuevo en la corte tras rechazar una oferta del regimiento de Valladoiid para permanecer alif hasta las fiestas del Corpus. Realizó los autos sacramentales ${ }^{40}$ de Madrid y consiguió una licencia similar a la de 1584 y 1586 que le permitía además representar desde el segundo día de Pascua Florida hasta el Corpus, tres dias de trabajo por semana, más las fiestas y los domingos.

En 1590 representó los autos del Corpus de Toledo ${ }^{41}$. El acuerdo para hacerse cargo de estas obras se firmó en enero de ese año. Marchó después a Valencia, donde trabajó entre mediados de junio y finales de octubre $^{42}$, regresando de nuevo a la ciudad imperial donde actuó en noviembre, como queda ratificado por el pago de alquileres en el Mesón de la Fruta hasta el dia de San Andrés de $1590^{43}$.

En julio de 1591 jerónimo Velázquez estaba en Madrid haciendo representaciones en los corrales de comedias de la corte y procurándose permisos especiales que le permitieran representar dos o tres días laborables además de los domingos y fiestas de guardar ${ }^{44}$. Este tipo de documentos que se multiplicaron durante la década de los ochenta y noventa, intensificaron en gran manera la actividad teatral de la corte. Los autores no eran los únicos interesados en que esto sucediera. Las otras directas beneficiarias eran las cofradías de socorro que administraban los corrales y que se sustentaban en buena parte con los beneficios de las comedias. Es por ello que entre las personas que testificaron a favor de las peticiones de Velázquez para representar en dias de diario, se en-

\footnotetext{
39 Ibidem, pág. 29.

40 Le encontramos preparando de nuevo el vestuario de estas obras. Por ejemplo, firma obligaciones con Juan de Saritllana y Francisco Sánchez, mercaderes vecinos de Madrid para pagar 5.400 reales por varias telas de Damasco, tafetanes y otras cosas que ha tomado de sus tiendas para la fiesta del Corpus de ese año. Madrid 26 de mayo de 1589, y se obliga con 50 ducados "precio de dos ferreruelos que compró" en 4 de marzo de 1589. AHPM, prot. 1306, sin folios.

41 Diez de Escobar, N., Anales..., op. cit, págs. 22-23.

4? Merimié, H., of. cit., pág. 127

${ }^{43}$ Documento inédito. AHPM, prot. 2.048. Obligación de pago de Jerónimo Velázquez a favor del Pedro del Campo: «Obligación de dar e pagar a Pedro del Campo en Toledo 400 reales de plata castelianos por remate de las representaciones que se han hecho en el mesón de la Fruta, que está a cargo de dicho Pedro del Campo el día de San Andrés de $1590 \%$.

${ }^{44}$ Varios documentos inéditos procedentes del Archivo de Protocolos de Madrid así lo prueban: AHPM prot. 1181, fol. $802 \mathrm{r}$ a $805 \mathrm{v}$.
} 
contraban los testimonios de diputados de las cofradias de la Soledad y de la Pasión ${ }^{45}$.

Durante el año de 1592 debió permanecer Velázquez en Madrid la mayor parte del tiempo. Aunque no se ocupó de las fiestas del Corpus, figura como fiador de los autores de comedias que lo hicieron, Gaspar de Porres y Rodrigo de Saavedra, ambos actores formados en su compañía como veremos ${ }^{46}$. A comienzos de la temporada de invierno, en noviembre, se encontraba en Sevilla demandando al Ayuntamiento permisos especiales para representar en dias de diario tal y como lo habia hecho antes en Madrid. Es muy posible que los permisos obtenidos en la corte fueran utilizados por Velázquez en la ciudad del Guadalquivir para mostrar al cabildo hispalense cómo los permisos que pedia no eran una novedad y se concedian en Madrid con el consentimiento del Consejo de Castilla. Las discusiones en el ayuntamiento sevillano fueron bastante duras. Expresaron su negativa a conceder tales permisos varios regidores, pero lo cierto fue que al final, tras comprometerse Velázquez a permanecer en Sevilla hasta las fiestas del Corpus de 1593, consiguió las licencias especiales que anhelaba ${ }^{47}$.

En 1594 el ayuntamiento de Madrid le encargó de nuevo realizar dos autos de los cuatro que la villa preparaba ${ }^{48}$, aunque no está muy claro que Velázquez finalmente aceptara, pues lo encontramos en Toledo de marzo a junio recibiendo libramientos a cargo de los autos del Corpus que iba a representar en aquella ciudad ese mismo año ${ }^{49}$. Unos meses

\footnotetext{
${ }^{45}$ AHPM, prot. 1185, fol. 803. "Jerónimo Velázquez, por más información de lo contenido en un pedimento, presenta como testigo a Bautista López (Criado de S. Mg. vecino de Madrid, de la cofradía de la Soledad y Niños Expósitos que lleva parte en las Comedias), que dice bajo juramento que asistiendo a la cobranza de la dicha parte que tiene la cofradia ha visto que por mandato supremo del Consejo de S. Mg. tiene orden y licencia los autores de comedias de representar tres dias de trabajo en cada semana, más las fiestas, esto sin contradicción de ninguna persona que lo impida y asimismo, ha visto que veinte o treinta días antes de Carnestolendas se les da licencia para cada día y esto es lo que sabe". Madrid 30 de julio de 1591.

46 Tomillo, A., y Pérez Pastof, C., op. cit, pág. 140.

47 Rodriguez Marin, F., Aportaciones para la historia del Histrionismo Español de los siglos xvi y xvm. Madrid 1914, págs. 9 a 12. Reproduce las actas capitulares del Archivo Municipal de Sevilla. Escribania primera. Sevilla 4, XI-1592.

48 Perez Pastor, C., "Nuevos datos sobre el Historicismo español", Bulletin Hispanique, tomo IX, 197, pág. 360.

49 Documentos inéditos procedentes del Archivo Catedralicio de Toledo (ACT). Obra y Fábrica, lib. 898, fol. 11. En él se dice lo siguiente: «Páguese por libramiento a Jerónimo Velázquez, autor de comedias, 500 reales. Toledo 9 de marzo de 1594.» Unas páginas después dice: «Páguese por libranza a Jerónimo Velázquez 200 reales. Toledo, 18 de junio de 1594\%. Estos pagos sólo podian proceder de las representaciones del Corpus en las que e! cabildo catedralicio de Toledo intervenía de forma directa.
} 
más tarde, y con una estacionalidad similar a la de 1590, se instaló de nuevo en Valencia. Alli permaneció entre el 11 de julio y el 17 de octubre ${ }^{50}$.

A comienzos de! año 1595 Velázquez se encontraba en Madrid. Fue entonces cuando apartó la querella que mantenía contra Lope de Vega, perdonándole y suplicando a los alcaldes de Casa y Corte que permitieran al poeta entrar en Madrid de nuevo sin esperar los dos años de destierro que aún le quedaban. Todo parece indicar que hubo un encuentro en Valencia - por otro lado inevitable dados los ambientes profesionales que ambos frecuentaban- entre el poeta y Velázquez durante el otoño del año anterior. Dos razones debieron inclinar a nuestro autor a perdonar a Lope. Una el paso del tiempo desde que se produjo la ofensa. La otra el resonante éxito que Lope cosechaba en aquella ciudad y que le hacía contar cada vez con más partidarios en los círculos teatrales ${ }^{50 \text { bis. }}$

En abril de 1595 Velázquez se encontraba en Valladolid formando compañia para poder representar durante la Pascua Florida ${ }^{51}$. En 1596 su fama era lo suficientemente grande todavia como para estar encargado de los autos sacramentales del Corpus de Toledo ${ }^{52}$.

Parece ser que éste fue su último año de actividad teatral, aunque Sánchez Arjona recoge un testimonio sobre la representación de un auto

\footnotetext{
so Merimée, H., op. cit., pág. 127

5o bis «A 18 de marzo de 1595 parescio Jerónimo Velázquez, autor de comedias y dixo que por quanto se querelló en auto criminalmente de Lope de Vega en razón de decir habia hecho cierta sátira contra Elena Osorio, su hija, y otras personas el año pasado de $87(. .$. perdona a Lope de Vega de todo delito que cometió y pide pueda volver a la Corte levantándose el destierro». AHPM prot. 1483 , sin foliar.

5t Fernández Martin, L., op. cit., pág. 29

s2 Según consta en un documento inédito del Archivo Catedralicio de Toledo, Sección de obra y Fábrica lib. 1317, fol. 116v-117r y que dice asi: «En la cibdad de Toledo a 10 dias de hebrero de 1596 años, paresció presente Francisco Diaz Fernández vecino de Toledo, por si y fiador de Jerónimo Velázquez autor de comedias y su compañia, cuyo poder mostró y le puso ante Juan de Uceda, escribano, ante quien pasó la obligación y dijo que por cuanto a: dicho Jerónimo Velázquez y sit compañia, han tratado con los señores Ginés de Soto Serrano y Dr. Francisco de Espinosa, canónigos y mayordomos de la Sta. Iglesia de Toledo de que harán la fiesta del Corpus Christi de este año de 1596 por precio de 5.000 reales y 500 reales por la venida con las condiciones y posturas contenidas que paso este dia ante el dicho Juan de Uceda, obligó su persona y la del dicho Jerónimo Velázquez a que harán la dicha fiesta, el dicho dia del Corpus en la forma contenida en la dicha escritura y para lo cumplir obligó la persona y bienes del dicho Francisco Piodriguez y su Compañia y por que se lo haga cumplir, por si y por el dicho Velázquez y Compañia, dio poder a las justicias eclesiásticas y seglares para que se lo hagan cumplir como por sentencia definitiva. Toledo 10 de febrero de $1596 \%$
} 
Jerónimo Velázquez. Un hombre de teatro en el periodo de ...

del Corpus en Sevilla en 1598 por un tal Alonso Velázquez ${ }^{53}$. Sea como fuere no parece que entrara en el siglo XVII permaneciendo en las tablas ${ }^{53}$ bis.

Como hemos visto, su actividad se centró principalmente en la corte, siendo uno de los protagonistas máximos del espectáculo teatral durante el último cuarto del siglo xvi. Además, la actividad teatral de Velázquez en Madrid contribuyó a satisfacer la demanda creciente de espectáculo y beneficencia de una villa que se habia convertido en la residencia permanente de los reyes de la Monarquía Hispánica.

\section{Su compañía: escuela de actores y autores de comedias}

A lo largo de este trabajo hemos intentado aproximarnos también a los actores que colaboraron con Velázquez, que se formaron con él y que en muchos casos siguieron sus pasos hasta convertirse en autores de comedias independientes. Por desgracia nos ha resultado imposible conocer la composición de su compañia durante cada uno de los años que representó, pero sí hemos podido saber, con las fuentes fragmentarias con las que contamos, el tamaño aproximado de la misma, las condiciones de contratación de los actores, los lugares en donde éstos se reclutaban y la evolución y progresión de algunos de ellos en el oficio teatral.

La noticia más completa que tenemos sobre la compañía de Velázquez es la que data de los actores con los que trabajó en la fiesta del Corpus de 1590 en Toledo ${ }^{54}$. Su compañia estaba compuesta por las siguientes personas:

- Rodrigo de Saavedra.

- Juan de Vera, músico.

- Jerónimo de Gálvez, «mi compañero y autor».

- Pedro Rodríguez y Mari Flores, su mujer.

- Miguel Ruiz y Ana Ruiz, su mujer.

53 Sánchez Arjona, J., El teatro en Sevilla en los siglos xvi y xvil. Sevilla 1887 (ed. consultada: Sevilla, ed. Padilla, 1990, pág. 280). En las noticias sobre la actividad teatral también aparece un Alonso Velázquez. Por tanto, es posible que fuera otra persona.

${ }_{53}$ bis Un indicio claro del abandono de su trabajo teatral es que en una escritura de renovación de censo otorgada por él, en 1599, cuando se alude a su profesión se dice «Jerónimo Velázquez, autor que fue de comedias». 14 de septiembre de 1599. AHPM, prot. 2069, fol. 843 .

${ }^{54}$ Biblioteca Nacional (BN). Papeles del Maestro Barbieri. Mss. 14.046, fols. 166 a 169. Ante mí Alonso de Granada. Madrid, 10 de enero de 1590. Cit., por Tomillo y Pérez Pastor. 
- Luis Calderón y Jerónima de los Ángeles, su mujer.

- Pedro de Zorita.

- Fabián de Ribera.

- Juan de Almaguer.

- Melchor de Villalba.

- Alonso Martínez.

- Jerónimo Manuel.

- Cristóbal Calderón.

- Diego de la Rocha.

Esta compañia se habia constituido en Madrid. En total estaba compuesta por diecisiete personas, trece actores, tres mujeres y un músico.

Con la simple observación de la lista podemos apreciar varias de las caracteristicas conocidas de las compañias de teatro de este periodo. En primer lugar, la presencia de mujeres, tolerada solamente en tanto en cuanto éstas estuvieran casadas con miembros del propio elenco para poder llevar una vida «decente» que no desatara escándalos notorios.

En segundo lugar, resulta evidente la escuela de teatro que supusieron las compañías de representantes. La presencia de Jerónimo de Gálvez, autor y actor de comedias entre 1579 y 1591, la de Rodrigo de Saavedra, autor de comedias en 1592, y la de Melchor de Villalba, también autor-actor entre 1592 y 1605. Sin duda, la compañía de Velázquez fue escuela práctica de otros autores de comedias. La formación y el estatus interno de los componentes eran similares a los que tenian los artesanos de otros oficios dentro de los talleres y obradores.

El tercer rasgo definitorio que se aprecia es la existencia de vínculos familiares muy estrechos entre las personas que se dedicaban al teatro. Existian familias enteras dentro del mundo teatral $y$, a veces, dentro de una misma compañía. No sólo matrimonios sino hermanos, yernos y cuñados que compartian escenario y beneficios. Estos comportamientos socioprofesionales no difieren, por lo demás, de los comportamientos endogámicos propios de la época. Parecidas actitudes las encontramos entre mercaderes o artesanos dedicados a las más variadas actividades.

Si estas caracteristicas resultan bastante claras, otras no nos resultan tan evidentes y quizá valga la pena profundizar un poco más en ellas. Si partimos de la composición de la compañia de Velázquez en 1590, se puede apreciar que hay unos comediantes vertebrales que actuaron en la compañía de modo más continuado, colaborando con el autor estrechamente durante más de una temporada, aunque renovaran su compromiso año a año. 
Jerónimo Velázquez. Un hombre de teatro en el periodo de ...

Entre estos elementos más o menos fijos se encontraría el yerrio de Velázquez, Cristóbal Calderón, o el propio Gálvez que parece se formó en la compañía de Velázquez hasta que decidió emanciparse de éste, aunque conservándo los viejos vínculos de amistad que les unían. Caso similar sería el de Rodrigo de Saavedra que en 1592 era ya autor en solitario. Junto a éstos aparecen actores contratados sólo por una temporada, normalmente desde marzo-abril hasta el carnaval del año siguiente -febrero-, y que solían reclutarse no sólo en los lugares en donde el autor comenzaba a formar la compañía, en el caso de Velázquez en Madrid, sino también en aquellos otros donde se iniciaba la temporada.

La compañia de Velázquez ofrece algunos ejemplos entre sus actores que ilustran esta última afirmación. Uno de sus representantes durante la temporada de 1583, Jerónimo Rodríguez, fue reclutado en Sevilla en donde Velázquez debió representar en abril durante la Pascua Florida ${ }^{55}$. En 1588 contrató a Antonio de Villegas, vecino de Sevilla por una temporada ${ }^{55}$ bis. Un ejemplo más claro nos 10 ofrece todavía el poder que Jerónimo Velázquez dio a su yerno Cristóbal Calderón en marzo de 1588 para contratar actores en Salamanca, donde comenzaría a representar en abril, para que se incorporaran a su espectáculo durante aquella temporada ${ }^{56}$.

Por otro lado hemos señalado ya cómo la organización interna de la propia compañía era similar a la jerarquización existente en otras actividades de carácter artesanal. Ciertamente, en las compañias de comedias existian por un lado el autor de comedias similar en sus atribuciones al maestro de un taller o un obrador, después los representantes llamados a menudo oficiales de comedias y cuyo segundo nombre indica el paralelismo con el estadio de los oficiales artesanos, y por último, se encontrarian los aprendices denominados en el ambiente teatral ayudantes o también e indistintamente, aprendices. Las categorías, obligaciones y privilegios propios de este "oficio de representar» quedan bien especificados en los contratos de comediantes vinculados con la compañia de Velázquez que hemos encontrado y que pasamos a analizar a continuación.

Empezaremos en primer lugar con los aprendices. Contamos con tres contratos inéditos de este tipo de comediante ${ }^{57}$. Los aprendices que con-

\footnotetext{
${ }^{55}$ Fernandez Martin, L., op. cit., pág. 28.

sis bis AHPM, prot. 864, sin foliar.

56 Ibidem.

57 Estos contratos son el de Jerónimo Ruiz que se encuentra en el AHPM, prot. 852; el de Lucas de Castro, ibidem, ambos contratados en 1576 y el de Garcia de Jaraba, contratado en 1577 , ibidem, prot. 856 .
} 
trató Jerórimo Velázquez para su compañia tenian unas características muy similares a las de los ambientes artesanales:

- En primer lugar eran «menores» es decir mayores de catorce años pero sin haber cumplido los veinticinco.

- Se les contrataba por una temporada teatral. Normalmente antes del Corpus para acabar el último día de carnaval (martes de Carnestolendas).

- Sus obligaciones eran servir en el oficio de representar y uen lo a él anexo», es decir, todo tipo de trabajos menores.

- Sus derechos consistían en comer, beber, dormir en cama, lavarles las camisas y no ir a pie en los viajes; lo harían bien en cabalgadura o en carro. La calidad del tratamiento sería la de criado.

- Con respecto al salario que debían recibir, éste variaba en cada contrato, pero se les podia pagar por temporada completa o según las representaciones que hicieran. En el caso de dos de los aprendices de Velázquez - Jerónimo Ruiz y Lucas de Castro contratados en la primavera de 1576 - recibirian el primero treinta ducados y el segundo veinticuatro por toda la temporada de trabajo. Otro de los menores contratado por Velázquez al año siguiente, García de Jaraba, recibiria un real por cada representación que se hiciera, más cuarenta reales por las del Corpus.

Si ascendemos un escalón más en la categoría de los comediantes, nos encontramos con los oficiales de comedias. De éstos también contamos con algunos ejemplos de contratos pertenecientes a la compañía de Velázquez. Uno de ellos es el compromiso que realizó al comienzo de su actividad con Juan de Sigura en 1574. La duración del mismo era como en los casos anteriores por una temporada. El salario sería de cien ducados, aproximadamente, cuatro veces más que un aprendiz y entre sus derechos estaría el de darle de comer y beber, cama y posada, lavarle la ropa y «llevarle y traerle caballero donde quiera que fuere» ${ }^{58}$.

Similares caracteristicas tiene el contrato que realizó con un cantante, Pedro de Almenara en 1589. Este se comprometia a entrar en la compañia de Velázquez ganando siete reales diarios más tres de ración, velas y ropa limpia. A cambio se obligaba a representar y cantar lo que le tocare hasta Carnestolendas de $1591^{59}$.

58 Perez Pastor, C., Nuevos datos..., op. cit., vol. I, págs. 334.

59 Tomll. Lo, A. y Perez Pastor, C., op. cit., pág. 146 
Jerónimo Velázquez. Un hombre de teatro en el período de ...

Un grado más dentro del de oficial de comedias, debió ser el que ocupaba Gálvez en la compañía de Velázquez. Algo parecido a un primer actor. Así lo demuestra el contrato que ambos firmaron en enero de $1590{ }^{60}$ y en el que Gálvez se comprometía a:

... «destar e andar con él en su compañía, (..) e ayudar (..) a representar qualesquiera comedias y autos e otras qualesquier cosas que durante el dicho año representare a qualesquier fiestas e negocios, ansi en estadicha villa como en otras qualesquier partes destos reinos e señorios (..), haciendo qualquier figura que se le pidiere e ordenare".

Por tanto aunque Velázquez le denomina «mi compañero», está muy claro en su contrato que entre las atribuciones que tenia en la compañia, no se encontraba la de dirigir a los actores. A pesar de su situación de privilegio, se encontraba supeditado a la voluntad de Velázquez.

Al vincular de este modo a Gálvez en su quehacer teatral, prestigiaba aún más a su compañía. Es probable que Gálvez hubiera representado ya en varias ocasiones como autor, pero los altibajos del oficio le debieron obligar en más de una ocasión a ponerse al servicio de compañías más consolidadas, cuando no había conseguido montar su propia agrupación de actores.

No conocemos muchos casos como el de Gálvez, pero sabemos que no fue ésta la única ocasión que lo hizo, ni fue el único autor que en un momento determinado formó parte de compañias más estables. Por ejemplo, en Madrid durante el período 1579-1586 los dos autores-actores italianos más prestigiosos del momento, Ganassa y Botarga, trabajaron ocasionalmente dentro de las compañías de Velázquez en 1582, el primero y con Alonso Rodríguez y Tomás de la Fuente, en 1583, el segundo. El propio Gálvez no sólo trabajó como primer actor para Velázquez sino también con Granados en 1579.

Las condiciones en las que Velázquez contrató a Gálvez fueron las de tener posada y cama para él y para un criado y proporcionarle a este último comida y bebida, así como una cama. Si Gálvez quería comer en la casa de Velázquez podía hacerlo, sino se le pagarían cuatro reales diarios para este menester. Si caía enfermo durante menos de quince días, las costas correrían a cargo de Velázquez. Los viajes se harían en cabalgadura para el criado y en silieta para Gálvez. En cuanto al salario, Gálvez cobraría tres mil reales en doce pagas más cuatro reales por cada

${ }^{60}$ AHPM, prot. 865 . 
representación, cien ducados el día de carnaval y dieciséis reales más los dias de representación cercanos a la Cuaresma

Como puede apreciarse, una perfecta jerarquización dominaba la vida de la Compañía. Jerarquización que garantizaba su funcionamiento dejando muy claro quién debia ser el rector de ella.

No parece que la compañía de Velázquez ofreciera las caracteristicas que tuvieron otras, y en las que varios actores se unian formando compañia propia y repartiendo a prorrata los beneficos obtenidos. Aquí la dirección quedaba bastante clara y del mismo modo se sabia el puesto y las atribudiones que cada uno de los representantes tenía.

\section{VELÁZQUEZ, EL HOMBRE}

Los avatares biográficos de Jerónimo Velázquez han trascendido hasta nosotros, sobre todo por sus vinculaciones «quasi» familiares con el joven Lope de Vega en Madrid a fines de la década de los ochenta, y por el episodio novelesco que tanto el poeta como el autor de comedias protagonizaron a raíz de los versos difamatorios que Lope de Vega dedicó al autor objeto de nuestro estudio, y que le costaron la pena de destierro de la corte. Pero ¿quién era en realidad Jerónimo Velázquez?

Hemos visto su brillante evolución como autor de comedias, pero además del éxito en el teatro, pretendió y consiguió que su progenie ascendiera socialmente a pesar de la rémora que podia suponer su propio oficio. Del mismo modo obtuvo un mediano pasar de rentista que le permitió retirarse de su azarosa y sobre todo errante vida de cómico. Dos facetas que parece no concuerdan demasiado con el estereotipo de comediante que tradicionalmente manejamos y que son escasamente conocidas.

Con respecto a su vida, según los datos que sobre él aporta Pellicer ${ }^{61}$, Jerónimo Velázquez era natural de Toledo y residía en la calle de Lavapiés en Madrid.

\section{Su familia}

Nada hemos conseguido saber de sus padres y de su familia de origen. Tan sólo que como buen cristiano se ocupó de las almas de sus

\footnotetext{
${ }^{6}$ Pellicer, J., Tratado histórico sobre el origen y progresos de la Comedia y del Histrionismo en España. Madrid 1804, vol. II, pág. 141.
} 
Jerónimo Velázquez. Un hombre de teatro en el periodo de ...

antecesores a la hora de morir encargando para ellos cincuenta misas ${ }^{62}$. También tenemos noticia de la existencia de un hermano que además era vecino suyo y que se llamaba Diego Velázquez, de oficio solador ${ }^{63}$ y de una hermana llamada Antonia ${ }^{63}$ bis. Si sabemos algo más de la familia que él fundó. Casó con Inés Osorio, cuya instrucción no era muy amplia, ya que la encontramos en documentos notariales de la época diciendo que no puede firmar porque no sabe. La fortuna personal de su esposa no debió ser muy grande, pues tras su muerte acaecida antes de 1609, Velázquez dice de ella que le dejó escasos bienes muebles «de muy poco valor» ${ }^{64}$. Fruto de este matrimonio tuvo al menos dos hijos que llegaron a edad adulta. Una niña llamada Elena Osorio, la famosa pretendida de Lope, y un niño, Damián Velázquez de Contreras, que se desvinculó en sus actividades profesionales del mundo teatral por expreso deseo de su padre, siendo doctor en Leyes. Parece ser que tuvieron otra hija llamada Jerónima que murió joven. Tras finalizar sus estudios, Damián marchó a América antes de 1612 y desempeñó en Cartagena de Indias el cargo de consultor del Santo Oficio de la Inquisición. Con posterioridad obtuvo el nombramiento de teniente general del gobierno de La Habana. Volvió a España en 1616 para concertar el matrimonio de su hija Jerónima con el licenciado Melchor de la Cueva y para arreglar algunos asuntos de su hacienda. Regresó a América en 1620 dejando a su hermana Elena Osorio poderes para administrar los bienes que tenía en Madrid ${ }^{65}$.

La biografía de la hija más famosa de Velázquez, Elena Osorio, si se encuentra más vinculada al teatro. Además de sus escarceos amorosos con Lope de Vega, casó a comienzos de la década de los ochenta con un comediante de la compañía de su padre, Cristóbal Calderón. Este actor no fue uno más entre los comediantes que dependian de Velázquez. Como hemos visto, actuó más de una vez como su «alter ego" contratando actores en otras ciudades y buscando compromisos de representación para la compañia. No tuvo hijos y debió morir antes de 1603 sin que Elena Osorio volviera a contraer matrimonio.

62 Ver apéndice doc. i. Testamento.

63 Así consta en un poder que dio Cristóbal Calderón, el marido de Elena Osorio, en noviembre de 1582 y en el que firmó Diego Velázquez como testigo. AHPM. Poder de Cristóbal Calderón a su hermano Eugenio de Espinosa y a su mujer Elena Osorio. Pedro de Salazar, prot. 909

63 bis De Antonia Velázquez tan sólo tenemos la noticia que casó con Lorenzo de Monteroso y que dejó un censo a favor del Monasterio de la Santísima Trinidad en 1617. AHPM, prot. 2485 , sin foliar

Gi Apéndice doc. I. Testamento.

55 Tomillo, A y Pérez Pastor, C., op. cit. pág. 165. Ver en apéndice doc. iV, cuadro genealógico de la familia de Velázquez. Noticias sobre su hermana Jerónima en AHPM, prot. $280,1-1 X-1576$. 
Aunque en el testamento elaborado por Velázquez en 1610 se dice que Cristóbal Calderón murió sin tener bienes propios, sí los tenia cuando se casó con su hija según reza en algunos documentos notariales en los que encarga a su mujer y a su hermano que vendan una casa de su propiedad en $1582{ }^{66}$. Tras la muerte de su marido, Elena Osorio llevó una vida relativamente desahogada de rentista y no murió hasta 1637.

\section{Origen y evolución socio-económica}

Antes de que los escenarios se cruzaran en el camino de Velázquez, éste habia aprendido el oficio de solador, al igual que su hermano. Así al menos consta en varios documentos firmados por él en la década de los setenta y en los que todavía no se alude a su oficio de autor de comedias. Es muy probable que ejercieran esta profesión de forma conjunta hasta que Jerónimo comenzó sus actividades teatrales ${ }^{67}$.

A mediados de la década de los setenta debió abandonar definitivamente la profesión de solador. Es posible que el esclavo que vendió en 1575 por 65 ducados fuera la persona que le ayudaba en su primitivo trabajo ${ }^{68}$.

A mediados de la década de los sesenta ya estaba instalado en la actividad teatral y como hemos visto empezó a cosechar algunos éxitos. Nos interesa ahora ver cómo invirtió parte de los beneficios económicos obtenidos en las tablas a lo largo de su vida.

Lo encontramos, por ejemplo, como dueño de una casa a comienzos de los años ochenta, plenamente instalado en las actividades teatrales, comprando dos solares en el barrio de Lavapiés el 6 de junio de 1582 por ochenta ducados ${ }^{69}$ pagados en dos plazos, uno en septiembre y otro en diciembre. Velázquez demostró ser un hombre previsor y estas compras y otras, que más adelante citaremos, así lo demuestran. También por es-

56. AHPM, prot. 909. Poder de Cristóbal Calderón a su hermano Eugenio de Espinosa y a su mujer Elena Osorio para que puedan vender una casa propiedad de Cristóbal Calderón y un solar en la calle de la Cruz con amplios poderes para establecer el precio, 17 de noviembre de 1582. Elena Osorio tardó tan sólo cuatro meses en encontrar comprador para estas posesiones pues las vendió el 4 de febrero de 1583, $1 \mathrm{bidem}$

${ }^{67}$ Efectivamente, su profesión de solador no quedaba demasiado lejana pues en una escritura de venta de un esclavo recogida por Pérez PAstor, C., Nuevos datos..., op. cit., vol. 11, pág. 2, correspondiente al año 1575, figura todavia con este oficio y no con el de autor de comedias.

68 Tomillo, A., y Pérez Pastor, C., op. cit., págs, 136 y ss.

59 AHPM, Carta de venta de Jusepe Vázquez calcetero, Cristóbal de Cuevas, prot. 858, año 1585. 
Jerónimo Velázquez. Un hombre de teatro en el período de ...

tos años su hija Elena Osorio se había casado ya con Cristóbal Calderón que poseía algunos bienes inmuebles en Madrid.

Continuó Velázquez, a pesar de su errática profesión, siendo vecino de Madrid. Estando ausente en Burgos por causa de su trabajo, encontramos a su mujer en julio de 1585 suscribiendo un censo al quitar a favor de Gaspar Maldonado, un menestral de Madrid que parece ser pertenecía al circuio de amistades del propio Velázquez, pues se encuentra en documentos notariales anteriores firmando como testigo en alguno de ellos.

Velázquez se vio obligado a suscribir este tipo de préstamos hipotecarios con amigos y allegados en numerosas ocasiones a lo largo de su vida $^{70}$. La razón era que, dadas las características irregulares de sus ingresos por la realización de comedias y la estacionalidad con la que éstas se representaban ${ }^{71}$, a veces no dispusieron del liquido necesario para las inversiones que debian hacer al iniciar una nueva temporada teatral. Por ello, Velázquez y su mujer no tuvieron más remedio que acudir a préstamos en los que ponían como garantía sus bienes más sólidos ${ }^{72}$. Estos documentos son útiles no sólo para ver en qué momentos Velázquez y su familia tuvieron falta de liquidez, sino que nos dan pistas sobre el paulatino crecimiento de su patrimonio personal.

Tras el destierro de Lope (1588), la actividad teatral de Velázquez se mantuvo a buen nivei. También su afán por conseguir un patrimonio que le permitiera cierto respiro económico. En 1595 fundó un censo perpetuo a favor de un aposentador de corte, D. Luis de Buitrago, en el que ponía como garantía del pago tres casas en la calle de Lavapiés y cuatro so-

${ }^{70}$ Otros censos que Velázquez suscribió y que hemos encontrado a lo largo de nuestra investigación han sido el que hizo el 10 de noviembre de 1599 a favor de Catalina Rodriguez por 600 ducados de principal: AHPM, prot. 1770 ante Juan del Castillo y otro en septiembre de ese mismo año a favor de Pedro Meléndez por 200 ducados. Ibidem. Como se ve por las fechas, Velázquez debía hacer inversiones para preparar la temporada de invierno.

${ }^{71} \mathrm{La}$ actividad teatral, como es sabido, tenía uno de sus periodos bajos en los meses centrales del verano, al menos en las grandes ciudades, ya que era el momento de recoger las cosechas de cereales y las tareas del campo apartaban de las capitales a numerosos espectadores habituales de las comedias. Los actores se desplazaban a pueblos y lugares para seguir manteniendo sus actividad, pero sus ganancias no podian ser tan altas como cuando trabajaban en las ciudades.

72 A.HPM, Uclés, prot. 477, 1585. Citado por A. Tomillo y C. Pérez Pastor en pág. 144: Concretamente Velázquez y su mujer debian a Gaspar Maldonado desde el 6 de junio de 1584, 200 ducados según una escritura de obligación que suscribieron y que, sin embargo, no pagaron. Es por ello que ahora, más de un año después, suscribieron un censo al quitar por importe de 5.357 maravedies, con interés de 14.000 al millar, es decir un 7 por 100 , aproximadamente. La garantia del pago del censo eran las casas que tenian en la calle de Lavapiés. 
lares que tenian en la puerta de Atocha ${ }^{73}$. Poseia además una casa en la calle de Majadericos, en la que vivió Lope antes de sus desavenencias con nuestro autor. Como vemos, su patrimonio inmueble había crecido bastante durante sus años de comediante.

A partir de 1603 se detecta cierta actividad liquidadora por parte de Velázquez, sobre todo en lo que se refiere a deudas contraídas merced a su actividad teatral. También se aprecia una clara tendencia a vivir de rentas compradas a lo largo de sus largos años de comediante - ya fueran alquieleres de casas, censos o juros-.

Por ejemplo, en enero de 1603 redime el censo fundado a favor de Pedro Meléndez cuatro años antes ${ }^{74}$. En febrero de ese año suscribirá otro a favor del monasterio de la Concepción Franciscana por valor de cuatrocientos ducados, ofreciendo como garantía además de las casas ya conocidas - de las tres de Lavapiés habia vendido una en 1599-varios censos que algunos particulares habían suscrito a su favor. Concretamente uno de 4.000 ducados con el conde de Siruela, otro de 500 ducados con un genovés llamado César Cornis y otro de 500 reales del licenciado Arias de Tapia. Por su parte su hija poseía una casa también en la calle de Lavapiés y algunos juros, uno de 20.000 maravedías al año sobre los Puertos Secos de los tres obispados de Sigüenza, Calatrava y Requena ${ }^{75}$, y otro de 1.403 maravedies al año sobre las Yerbas de la Orden de Santiago ${ }^{76}$. Disfrutaba además en 1606 de una casa en la calle del Sordo por el retraso en el pago de unos réditos por un censo no satisfecho ${ }^{77}$.

En 1610 Jerónimo Velázquez estaba retirado de las tablas. Según consta en el testamento que otorgó el 21 de noviembre de ese año, no lo pudo firmar por estar impedido de la vista ${ }^{18}$. Para entonces los solares de la Puerta de Atocha se habian convertido en casas. Sobrevivió al menos tres años más, pues aparece como fiador del hermano del difunto Cristóbal Calderón en 1613, aunque tampoco firma «por hallarse impedido en la cama». Alrededor de esta fecha debe situarse su muerte. Según Tomillo y Pérez Pastor, ésta acaeció el 25 de febrero de 1613, aunque no tenemos constancia documental de este hecho ${ }^{79}$.

\footnotetext{
3 Tomillo A., y Pérez Pastor, op. cit., pág. 140.

4 AHPM, Cristóbal Gálvez, 1603, prot. 2.790.

Ibidem, Juan Correa, años 1603, prot. 2.421.

Ibidem, prot. 1.156, apéndice III.

Ibidem, Juan de Obregón, 1606, prot. 2.436.

78. Ibidem, prot. 2.445. Apéndice I. Testamento.

79 Tomillo. A.: y Pérez Pastor, C., op. cit., pág. 141.
} 
Jerónimo Velázquez. Un hombre de teatro en el período de ...

Su última representación: vida y teatro

La estrecha vinculación de Velázquez con el mundo teatral se refieja al final de sus dias en la redacción de su testamento. No hay largas alusiones a su actividad en las tablas, pero entre sus albaceas testamentarios se encuentra Morales, famoso autor de comedias a comienzos del siglo XVII, con el que debió mantener estrechas relaciones de amistad además de las profesionales. Es muy posible que al abandonar los escenarios, Jerónimo Velázquez vendiera a Morales los hatos de sus representaciones, Morales seria, por así decirlo, su heredero en la actividad teatral.

Del mismo modo, al hacer balance de sus últimas voluntades, Velázquez, como un piadoso hombre de su tiempo, dejó encomendado hacer varias limosnas a diversas instituciones religiosas y de caridad. Las limosnas de mayor cuantia que Velázquez encargó tenian como destino, curiosamente, las cofradias de la Pasión y de la Soledad en Madrid. Eran éstas las instituciones que impulsaron la gestación del fenómeno teatral en la corte, creando lugares permanentes de representación y alentando en todo momento la actividad teatral durante los años ochenta y noventa del siglo xvı. Velázquez no sólo ofreció estas limosnas cuando sintió cercano el fin de sus días, sino que, como señalaba en su testamento, era cofrade de ambas.

El último detalle en la vida de un viejo comediante fue la minuciosa puesta en escena de su propio entierro. Dejó perfectamente establecida la comitiva que debía acompañarle en su último viaje: La cruz y clérigos de la iglesia de San Tiuste y Pastor del barrio de Lavapiés donde residia. Las cofradias de la Pasión, Soledad, Veracruz y Santa Elena por ser cofrade de todas ellas ${ }^{80}$, doce frailes de la Merced, doce de San Francisco y doce del Carmen. Por último, le acompañarían los niños de la Doctrina y transportarían su cuerpo hasta el monasterio de la Merced, donde sería enterrado, los hermanos de Antón Martín.

Aunque el recuerdo de su trabajo en el teatro se perdiera en pocos años quedando como una sombra anexa a la vida de Lope de Vega, pro-

\footnotetext{
${ }^{80}$ Aunque en el testamento no se cita, también perteneció a la cofradia del Santísimo Sacramento de San Sebastlán, donde ingresó el 19 de abril de 1607: "En dicho día se recibió por hermano y cofrade a Jerónimo Belázquez, el qual juró de obedeçer a los ofiziales e guardar las ordenanças y dio por entrada treinta y quatro reales y para ello dio por fiador a Pedro Martínez que lo açetó de que doy fée», en 19-IV-1607 Cofradía del Santísimo Sacramento", CSS, en AGuLlo y CoBo, Mercedes, "Cien documentos sobre teatro madrileño (1582-1824), págs. 83-138, dentro de la obra colectiva: El teatro en Madrid (1583-1925). Del corral del Principe al Teatro de Arte. Madrid, Ayuntamiento, 1983.
} 
curó no ser olvidado en su calidad de cristiano piadoso. Encargó por ello 264 misas repartidas entre el Monasterio de la Merced, el del Carmen, San Francisco y su Parroquia de Santiuste. Incluso ese último gesto le define como un tipico hombre de su tiempo; preocupado en vida por la conquista de una situación holgada y socialmente reconocida y en el trance de la muerte atento a la salvación de su alma.

\section{APÉNDICE I}

Testamento de Jerónimo Velázquez (AHPM, prot. 2.445)

«En el nombre de Dios todo poderoso. Conocida cosa sea a los que en la presente escritura de testamento, última e póstuma voluntad vieren, como yo Jerónimo Velázquez, vecino de la villa de Madrid, estando en la cama bueno y en mi buen juizio en rendimiento natural al que Nuestro Señor a sido servido de me dar, creyendo como firmemente creo en la Santisima Trinidad, Padre, Hijo e Espiritu Santo que son tres personas y un sólo Dios verdadero, confesando como confieso firmemente creo todo aquello que creyere e confiesa la Santa Madre Yglesia de Roma y llevado desta fe firme (...) temiéndome la muerte (...) hordeno y establezco (...) en la forma e manera siguiente:

Primeramente, encomiendo mi ánima a Nuestro Señor Jesucristo que me la dio a su imagen y semejanza y el cuerpo a la tierra de donde es y adonde fue formado

Y (...) que si Nuestro Señor fuere servido de me llevar de esta presente vida, mi cuerpo sea sepultado en la Yglesia del monasterio de Nuestra Señora de la merced de la villa en la sepultura que alli yo tengo con su piedra. Y se pague por el rompimiento y sepultura de mis rentas.

Item mando que acompañen mi cuerpo la Cruz y clérigos de la yglesia de Santiuste, donde soy parroquiano, y ansi mesmo me acompañen las cofradias donde soy cofrade y se paguen los derechos acostumbrados.

Item mando que acompañen mi cuerpo doze frailes dela Merced y doze de San Francisco y doze del Carmen y se les dé la limosna acostumbrada.

Item mando que acompañen mi cuerpo los niños de la Doctrina y se les dé lo acostumbrado. $Y$ ansi mesmo vayan ocho pobres acompañando mi cuerpo con achas encendidas y se les dé limosna, lo que a mis alvaceas les pareciere.

Item mando que en el dia de mi enterramiento o si fuere por la mañana a otro dia siguiente se diga por mi ánima en la iglesia del monasterio de la merced en la Capilla de Nuestra Señora de los Remedios, una misa cantada con un diácono (...). 
Item mando que se digan por mi ánima doze misas en doze altares previlexiados en la yglesia y sermones serios que les pareciere a mis albaceas y se pague la limosna acostumbrada.

Item mando se dispongan por mi ánima ziquenta misas del Oficio de Nuestra Señora de la Merced y otras zinquenta en Requiem o del oficio que rezare la yglesia quando se mandaren en él y que de todo se paguen los derechos acostumbrados.

Item mando se digan por mi ánima en el Monasterio de San Francisco desta villa treze misas de honor de San José y otras doze en el Monasterio del Carmen a honor del señor San Antonio de Padua.

Item mando se digan veinticinco misas para las ánimas del purgatorio a donde a mis albaceas les parecieren y se paguen los derechos.

Item mando se digan por mi ánima zinquenta misas en la Yglesia de Santiuste y Pastor dela villa donde soy parroquiano y se digan del officio que rezare la yglesia e cuando se mandaren de dar y se paguen los derechos de mis vienes.

Item mando se digan por las ánimas de mis padres y aguelos y difuntos zinquenta misas y se paguen los derechos de mis vienes.

Item mando por si acaso tengo algún cargo que no sé la quantia ni a quien es, se tomen seis bulas de composición por mi ánima y sea con la mayor brevedad que se pudiere.

Item mando a las cinco mandas forzosas a cada una medio real de plata y redención de cautivos otro medio.

Item mando por la canonización de San Isidro desta villa dos ducados y se paguen a las personas que lo tuvieren a su cargo.

Item mando que qualquiera persona de buena fama que viniere asegurando que yo le devo en quantia de reales se les paguen y den si lo pruevan.

Item mando para Nuestra Señora de la Soledad para el sustento y crianza de las niñas huérfanas que alli se recoxen dos ducados y se paguen de mis vienes.

Item mando a los niños expósitos desta villa zinquenta reales y les den luego de mis vienes.

Item a los povres que se aiaran en el ospital de la Pasión de la villa, zinquenta reales y se les den luego que yo fallezca.

Y mando que lleven mi cuerpo los hermanos del ospital de Antón Martín y se les dé de limosna lo acostumbrado e acompañen mi cuerpo las cofradías de la Soledad, Santa Elena, la Veracruz y la Passión donde soy cofrade, pagando las entradas e se pague lo que sea costumbre.

Item declaro que por quanto Cristóbal Calderón, mi yerno, marido de Elena Osorio, mi hija, por cláusula de su testamento con que murió, declaró que unas obligaciones que yo le avia firmado de ochocientos ducados de principal, avía sido en confianza y que yo le devía cossa ninguna dellos, declaro que es verdad (..). 
Porque la dote que yo le di con la dicha mi hija, la consumió y yo le traje conmigo en las comedias (...), e declaro que para descargo de mi conziencia yo no devo los ochocientos ducados ni cossa ninguna dellos, que la dicha obligación la hize en confianza y asi lo deciaro.

Item declaro que por fin e muerte de Inés Osorio, mi mujer, me quedaron muy pocos bienes muebles e después de muerta los he consumido, que heran de muy poco valor e los que de presente están en mi cassa son de Elena Osorio, mi hija, viuda del dicho Cristóbal Calderón, y así lo declaro para que en todo tiempo ésta es la verdad.

Declaro que tengo por vienes míos propios las casas en que vivo y otras en el ospital de Antón Martín, e Miguel Jerónimo e Maria Bernardo, mis esclavos, hijos de Maria Buzio, mi esclava e no otros algunos.

E porque del matrimonio con la dicha Inés Osorio, mi mujer, quedaron e tengo por mis hijos legitimos al Doctor Damián Velázquez de Contreras que al presente está en la ciudad de Cartagena de las Indias y a la dicha Elena Osorio, viuda del dicho Cristóbal Calderón, e porque yo tengo mucho amor e voluntad a la dicha Elena Osorio e querria quedase en puesto para poder conservarse a honrra después de mis días, para poderse mejor sustentar y atento que ella de su hazienda ayudó al dicho su hermano en sus estudios e a mi en muchas necesidades, socorriéndome en las que se me han ofrecido y otras justas razones que ello me mueven, por la presente usando de la facultad que la ley y el derecho me conceden, mando se den desde luego mi gozo a la dicha Elena Osorio en el terzio e rremanente de mis vienes para que los haya demás de su lexitima.

Mando además a Antonia Velázquez, mi nieta, hija del Doctor Velázquez, mi hijo, que se le dé a Miguel Jerónimo (es un esclavo) para que le sirva en la su casa e la dicha Maria Bernarda (la otra esclava de su propiedad), mando a la dicha Elena Osorio, mi hija, entrambos a rasa e no en propiedad e para cumplir e pagar este mi testamento las mandas e legados en él contenidos, nombro por mis albaceas e testamentarios a la dicha Elena Osorio, mi hija, primeramente, y al maestro Sebastián de Mesa, comisario del Santo Oficio, cura de la dicha mi parroquia y a Alonso de Morales y a Juan de Mesa, pintor, los quales (...) cumplan este mi testamento, e que doy poder cumplido para que entiendan en mis bienes, ellos vendan, rematen judicial o extrajudicialmente y el remanente que quedare de mis bienes muebles e rrayzes, derecho e bienes avidos e por haber cunplido este mi testamento, los de por mi a mis Universales Herederos en todos ellos, al dicho Doctor Damián Velázquez de Contreras y Elena Osorio, mis hijos, y que los ayan $y$ hereden, $y$ anulo $y$ doy por ninguno qualquier testamento o testamentos o codicilio o codicilios que antes deste aya (...).

En la villa de Madrid, a veintiuno de noviembre de mill e seiscientos e diez años. Testigos que fueron presentes Francisco Vázquez, Juan Martínez, Andrés González e Domingo Alonso e Lorenzo de Monterroso e el otorgante, que yo el dicho escribano doy fee $=$ el dicho olorgante no lo firmó por estar impedido dela vista. 
Jerónimo Velázquez. Un hombre de teatro en el período de ...

APÉNDICE II

Reconstrucción de la actividad teatral de Jerónimo Velázquez

\begin{tabular}{|c|c|c|c|}
\hline AÑO & LOCALIDAD & MESES & ACTIVIDAD \\
\hline 1564 & Madrid & enero & Alcázar de Madrid/Ante la Reina \\
\hline 1570 & Segovia & junio & Corpus \\
\hline 1574 & Madrid & junio & Corpus de Madrid \\
\hline 1575 & Madrid & junio & Corpus de Madrid \\
\hline 1576 & Madrid & junio & Corpus de Madrid \\
\hline 1577 & Madrid & junio & Corpus de Madrid \\
\hline 1578 & - & - & - \\
\hline \multirow[t]{2}{*}{1579} & Valladolid & agosto & \\
\hline & Madrid & sept.-octubre & Corral de la Puente \\
\hline 1580 & Muerte de la Reina & en oct. de este año & \\
\hline \multirow[t]{4}{*}{1581} & Alcalá de Henares & Mayo & Auto (¿a lo divino) \\
\hline & Piedrahita (Ávila) & julio (1 y 2) & Dos autos con entremeses \\
\hline & León & agosto & Auto a lo divino en la catedral \\
\hline & Valladolid & nov.-diciembre & Corral de la Cofr. de niños exp. \\
\hline 1582 & Madrid & enero-junio & En los tres corrales \\
\hline \multirow[t]{3}{*}{1583} & Sevilla & agosto & \\
\hline & Valladolid & septiembre & \\
\hline & Madrid & oct.-diciembre & \\
\hline 1584 & $\begin{array}{l}\text { Madrid } \\
\text { Valencia }\end{array}$ & $\begin{array}{l}\text { enero-junio } \\
\text { junio-octubre }\end{array}$ & $\begin{array}{l}\text { Incluido el Corpus de Madrid } \\
\text { Corral de la Olivera }\end{array}$ \\
\hline \multirow[t]{2}{*}{1585} & Burgos & julio & \\
\hline & Madrid & nov.-diciembre & \\
\hline 1586 & Madrid & enero-junio & Incluido el Corpus de Madrid \\
\hline 1587 & $\begin{array}{l}\text { Sevilla } \\
\text { Madrid }\end{array}$ & $\begin{array}{l}\text { junio } \\
\text { oct.-diciembre }\end{array}$ & Corpus de Sevilla \\
\hline \multirow[t]{3}{*}{1588} & Salaınanca & abril & Pascua Florida \\
\hline & Valladolid & junio & Corpus de Valladolid \\
\hline & Sta. Olalla (Vall.) & junio (dia 24) & Fiesta de San Juan \\
\hline 1589 & Madrid & abril-junio & Corpus de Madrid \\
\hline 1590 & Toledo & junio & Corpus de Toledo \\
\hline 1591 & Madrid & julio & \\
\hline \multirow[t]{3}{*}{1592} & & & Fiador de G. de Porres en el \\
\hline & Madrid & agosto & Corpus \\
\hline & Sevilla & nov.-diciembre & \\
\hline \multirow{3}{*}{1594} & $\begin{array}{l}\text { Sevilla } \\
\text { Madrid }\end{array}$ & enero-junio & Corpus de Sevilla \\
\hline & $\begin{array}{l}\text { Madrid } \\
\text { Toledo }\end{array}$ & marzo-junio & Corpus de Toledo \\
\hline & Valencia & julio-octubre & Corral de la Olivera \\
\hline
\end{tabular}


CARMEN SANZ AYAN - BERNARDO J. GARCIA GARCIA

\begin{tabular}{llcl}
\hline AÑO & LOCALIDAD & MESES & ACTIVIDAD \\
\hline 1595 & $\begin{array}{l}\text { Madrid } \\
\text { Valladolid } \\
\text { Toledo } \\
1596\end{array}$ & $\begin{array}{c}\text { Madrid } \\
\text { marzo-junio } \\
\text { marzo }\end{array}$ & $\begin{array}{c}\text { Pascua Florida } \\
\text { Corpus de Toledo }\end{array}$ \\
\hline
\end{tabular}

NOTA: En este cuadro tan sólo figuran los datos de los que tenemos alguna constancia documental. (Suposiciones tales como, por ejemplo, el que si Velázquez estaba en Madrid en junio, es probable que tuviera a su cargo algún auto del Corpus, aun siendo razonables, no figuran en el cuadro si no contamos con una prueba de que fue así).

\section{APÉNDICE III}

Posesiones de Jerónimo Velázquez y de Elena Osorio

\section{INMUEBLES}

- Una casa en la calle del Príncipe. En su poder hasta al menos 1566.

- Tres casas en la calle de Lavapiés. Una vendida en 1599.

- Una casa en la calle de Majadericos. Vendida antes de 1610.

- Cuatro solares en la puerta de Atocha. Se convertirán en casas antes de 1610. Son las casas que Velázquez llama del Hospital de Antón Martín *.

\section{CENSOS}

- 4.000 ducados de 14.000 al millar con el conde de Siruela.

- 500 ducados de 14.000 al millar con César Cornis (genovés).

- 500 ducados de 14.000 al millar con el licenciado Arias de Tapia.

- Disfrute de una casa (por deudas de un censo no saldadas) en la calle del Sordo.

* En 1618 Damián Velázquez de Contreras, el hijo de jerónimo Velázquez, labró unas casas principales que daban a la calle de Valencia, según traza de Juan Gómez de Mora. 
Jerónimo Velázquez. Un hombre de teatro en el período de...

JUROS

- Un juro de 20.000 maravedies sobre las rentas de Puertos Secos de los Tres Obispados.

- Un juro de 1.403 maravedies al año sobre las Yerbas de Santiago.

\section{ESCLAVOS}

- Dos esclavos: Miguel Jerónimo y Maria Bernardo, hijos de Maria Buzio. 


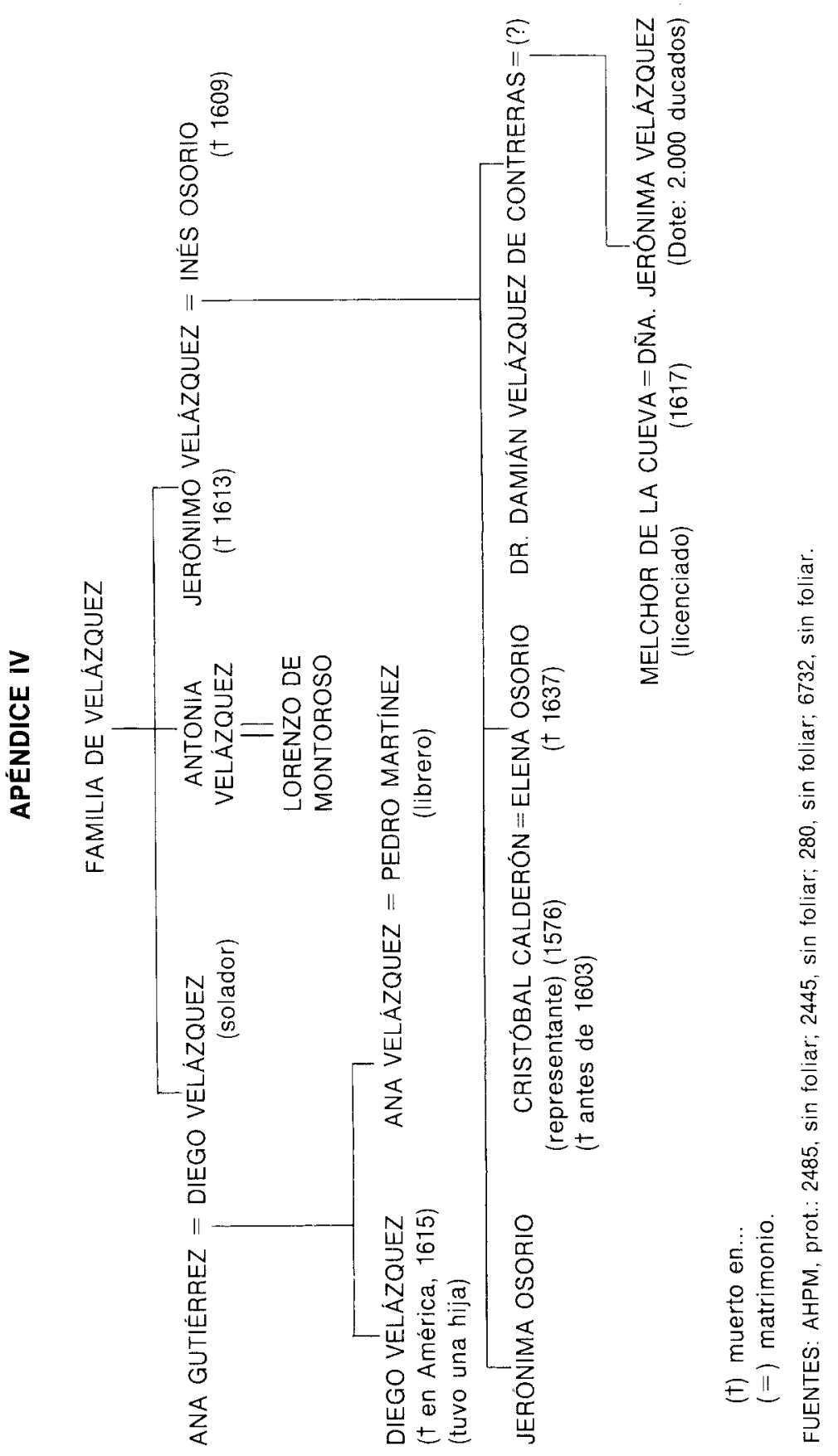


Jerónimo Velázquez. Un hombre de teatro en el período de...

\section{APÉNDICE V}

Calendario de representaciones de Jerónimo Velázquez en Madrid (15791586) *

1579 Corral de la Puente (En número el día que representó)

SEPTIEMBRE

L

M

$x$

v

$\mathrm{S}$

D

8

10

13

15

17

20

21

29

Día 8: Natividad; día 21: San Mateo; día 29: San Miguel.

\section{OCTUBRE}

L $\quad M$

$X$

$\checkmark$

V

S

D

6

1

4

8

11

1582 * Corral de La Cruz

ENERO

L

22
M

$\mathrm{X}$

17

23

30

27

\section{(1)}


ABRIL

$\begin{array}{ccccccc}\text { L } & M & X & J & V & S & \text { D } \\ 16 & & & 19 & & 21 & 22 \\ 23 & & & 26 & & & 29\end{array}$

Día 16: Pascua de Resurrección.

MAYO

L

M

8

14

28

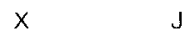

2

3

10

24

23

S

D

5

Día 24: La Ascensión.

JUNIO

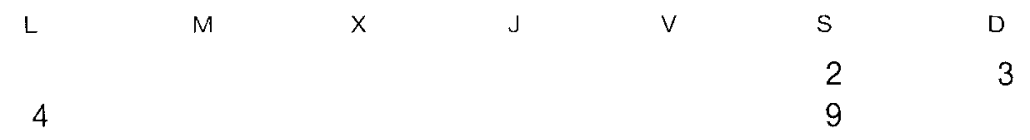

11

Dias: 2, 3, 4, y 5 Pascua del Espiritu Santo; Día 11: San Bernabé.

1582 Corral de la Pacheca

\section{ENERO}

L

M

x

v

S

D

29

FEBRERO

L

M

x

J

S

D

19

21 
Jerónimo Velázquez. Un hombre de teatro en el período de ...

ABRIL

L

$\begin{array}{ll}M & X \\ 17 & \end{array}$

25

Día 25: San Marcos.

MAYO

L

M $\quad$ J

V

$\mathrm{s}$

D

1

6

20

27

JUNIO

L

M

$\times$

V

S D

10

1582 Corral de la Puente

L

M $\quad \times$

J

V

s

D 18

1583 Corral de la Cruz

OCTUBRE

L

$\begin{array}{cc}M & X \\ 25 & 26\end{array}$

NOVIEMBRE

L

7

M

x

8

22

29
J

v

28

S

D

30 


\begin{tabular}{ccccccc}
\hline & & & & & & \\
\hline & $M$ & $X$ & $J$ & & & $\mathrm{~S}$ \\
19 & 13 & & 15 & & & 18 \\
26 & 20 & 21 & & & & 25
\end{tabular}

1583 Corral del Principe

NOVIEMBRE

L

$\begin{array}{ll}\text { M } & \times \\ 15 & 16\end{array}$

1584 Corral de la Cruz

ENERO

L

M

3

10

16

24

31

FEBRERO

L

M

$x$

J

v

S

D

8

13

ABRIL

L v

$\mathrm{s}$

7

28

22

29

D

1
5
12

26

20

$$
x
$$

25 
Jerónimo Velázquez. Un hombre de teatro en el periodo de ...

MAYO

L

$\begin{array}{lll}M & \times & \\ 1 & \end{array}$

J V

S

D

10

13

20

21

- ¡Atención!: Durante el mes de mayo de 1584 representa dos veces en el mismo día en distinto corral. Se le concede este privilegio para que se haga cargo de las representaciones del Corpus.

JUNIO

$\begin{array}{llllll}\text { L } & X & J & V & S & D \\ & & & 10\end{array}$

11

1584 Corral del Principe

FEBRERO

L

M

$x$

J

2

ABRIL

L

M

$x$

J

V

s

D

25

10

22

29

- ¡Atención!: Durante el mes de abril de 1584 representa dos veces en el mismo dia en distinto corral. Se le concede este privilegio para que se haga cargo de las representaciones del Corpus.

MAYO

L

$$
\begin{aligned}
& M \\
& 1
\end{aligned}
$$

$x$

3

$\mathrm{V}$

3
S

6

13

20

21

- Atención!: Durante el mes de mayo de 1584 representa dos veces en el mismo día en distinto corral. Se le concede este privilegio para que se haga cargo de las representaciones del Corpus. 
1584 Corral. de La Puente

$\begin{array}{lllllll}M & X & J & V & S & D \\ 14 & & & & & \end{array}$

1585 Corral. de la Cruz

NOVIEMBRE

L $\quad M$

$x \quad J$

S

D

30

DICIEMBRE

$\begin{array}{rrrrrrr}L & M & X & J & V & S & \text { D } \\ 2 & & & 5 & & & 1 \\ 9 & 10 & & 12 & & & 8 \\ & 17 & 18 & 19 & 20 & 21 & 22 \\ 23 & 24 & 25 & 26 & 27 & 28 & 29\end{array}$

1586 CoRRAL DE LA Cruz

ENERO

$\begin{array}{rrrrrrr}L & M & X & J & V & S & 0 \\ & & 1 & & 3 & 4 & 5 \\ 6 & 7 & 8 & 9 & 10 & & 12 \\ 13 & 14 & & 16 & & & 19 \\ 20 & & & & & & 26\end{array}$

FEBRERO

L

M

X $\quad$ J

$\checkmark$

$\mathrm{D}$

$\begin{array}{ll}10 & 11 \\ 17 & 18\end{array}$

56

6
13

$S$

2

12

8

9

18

1586 Corral del Principe

L

M

14

27 $x \quad 3$

v

s

D 